\title{
MENURUNKAN KEBIASAAN MENCONTEK MELALUI METODE APA? LANTAS, BAGAIMANA? DAN SEKARANG BAGAIMANA? DALAM BIMBINGAN KELOMPOK PADA PESERTA DIDIK KELAS VIII.1 SMP N 1 CITEUREUP
}

\author{
Rahayu Prihantari ${ }^{1}$
}

\begin{abstract}
Abstrak
Penelitian ini dilatarbelakangi berdasarkan kondisi realitas yang diperoleh melalui pengamatan dan laporan dari beberapa guru mata pelajaran dan pengawas yang terhimpun dalam catatan kasus yaitu $75 \%$ peserta didik mencontek pada saat ulangan Bila kondisi ini berkelanjutan dapat berakibat fatal karena bisa menyebabkan peserta didik tidak percaya pada kemampuannya, dapat membentuk sifat pembohong, memiliki potensi untuk menjadi koruptor atau penipu ulung. Penelitian ini merupakan penelitian tindakan kelas yang terdiri dari 2 siklus dengan tahapan kegiatan perencanaan, melakukan tindakan, observasi serta refleksi. Subyek penelitiannya adalah peserta didik kelas VIII.1 Tahun Pelajaran 2012/2013 SMP N 1 Citeureup yang berjumlah 44 orang. Metode penelitiannya dengan menggunakan metode Apa? Lantas Bagaimana? Dan Sekarang Bagaimana?dalam bimbingan Kelompok. Hasil penelitian menunjukkan tingkat kepuasan pada siklus 1 mencapai $80 \%$ pada siklus 2 mencapai 95\%. Keaktifan pada siklus 1 mencapai 77,6\% pada sklus 2 mencapai $83,2 \%$. Sedangkan pada kebiasaan mencontek menurun yaitu dari $45 \%$ pada siklus 1 menjadi $40 \%$ pada siklus 2. Dengan demikian kesimpulannya adalah Metode Apa? Lantas Bagaimana? Dan Sekarang Bagaimana?dalam Bimbingan Kelompok dapat menurunkan kebiasaan mencontek.
\end{abstract}

Kata Kunci: Metode Apa? Lantas Bagaimana? Dan Sekarang Bagaimana?dalam Bimbingan Kelompok, kebiasaan mencontek,

\begin{abstract}
This research is based on reality condition obtained through observation and report from some subject teachers and supervisor which collected in case note that $75 \%$ learners cheat during replication If this condition sustained can be fatal because it can cause learners do not believe in its ability, Can form the nature of a liar, have the potential to become corrupt or impostor.This study is a classroom action research consisting of 2 cycles with stages of planning activities, taking action, observation and reflection. The subjects of the study were students of class VIII.1 Year 2012/2013 SMP N 1 Citeureup which amounted to 44 people. The research method using the method What? So How? And Now How? In the guidance of the Group. The results showed that satisfaction level in cycle 1 reach $80 \%$ in cycle 2 reach $95 \%$. Activeness in cycle 1 reached $77.6 \%$ in skus 2 reached $83.2 \%$. While the habit of cheating decreased from $45 \%$ in cycle 1 to $40 \%$ in cycle 2. Thus the conclusion is What Method? So How? And Now How? In Group Guidance can lower cheating habits.
\end{abstract}

Keywords: What Method? So How? And Now How? In Group Guidance, habit of cheating,

\footnotetext{
${ }^{1}$ Guru Bimbingan dan Konseling SMP Negeri 1 Citeureup, rahayuprihantari67@gmail.com
} 


\section{PENDAHULUAN}

Pendidikan merupakan aspek yang sangat penting dalam menunjang kemajuan bangsa di masa depan. Melalui pendidikan manusia sebagai subyek pembangunan dapat dididik, dibina dan dikembangkan potensinya.

Misi pendidikan khususnya di SLTP (MTS) dan SLTA (SMA,MA, SMK, MAK) diantaranya adalah mempersiapkan para lulusannya agar memiliki akhlaq yang mulia, mental yang kuat dan kepribadian yang mantap.

Dalam pasal 3 UU No.20 Tahun 2003 tentang Sistim Pendidikan Nasional bahwa "Pendidikan Nasional berfungsi mengembangkan kemampuan dan membentuk watak serta peradaban bangsa yang bermartabat dalam rangka mencerdaskan kehidupan bangsa, bertujuan untuk berkembangnya potensi peserta didik agar menjadi manusia yang beriman dan bertaqwa kepada Tuhan yang maha Esa, berakhlaq mulia, sehat, berilmu,cakap, kreatif, mandiri dan menjadi warga negara yang demokratis dan bertanggung jawab.

Sekolah sebagai salah satu lembaga pendidikan formal harus berupaya secara maksimal, konsisten dan kontinu agar dapat melahirkan lulusan yang dapat diandalkan, memiliki kepribadian yang mantap, bersikap jujur, pecaya diri dan dapat mandiri

Kejujuran menjadi hal yang sangat penting dan mendasar yang harus dimiliki peserta didik. Namun kenyataan di sekolah masih banyak peserta didik yang belum mampu bersikap jujur. Salah satunya adalah mencontek di saat ulangan baik ulangan harian, ulangan tengah semester, ulangan semester/ulangan kenaikan kelas bahkan ujian nasional.

Di SMPN 1 Citeureup, berdasarkan pengamatan dan laporan dari beberapa guru mata pelajaran dan pengawas yang terhimpun dalam catatan kasus ditemukan $75 \%$ peserta didik mencontek pada saat ulangan. Mereka menggunakan berbagai cara diantaranya membuat catatan kecil di kertas, membuka buku atau LKS, bertanya kepada teman secara lisan atau dengan menggunakan isyarat atau bahkan menggunakan HP.

Jika kondisi ini terus dibiarkan secara langsung atau tidak langsung hal ini akan sangat mempengaruhi pembentukan karakter dan kepribadian bagi peserta didik itu sendiri dan berdampak dunia pendidikan semakin rendah kualitasnya dan bangsa menjadi tidak bermartabat karena memiliki generasi yang tidak jujur, malas, tidak percaya diri dan selalu ada kecenderungan untuk mencari jalan pintas yang menghalalkan segala cara untuk mencapai tujuan yang diinginkannya serta memiliki potensi untuk menjadi koruptor atau penipu ulung nantinya.

\section{ACUAN TEORITIK}

\section{Teori Variabel Masalah.}

\section{Pengertian mencontek}

Mencontek adalah kegiatan menggunakan bahan atau materi yang tidak diperkenankan atau menggunakan pendampingan dalam tugas-tugas akademik dan atau kegiatan yang dapat mempengaruhi proses penilaian. Perilaku mencontek sering dikaitkan dengan kecurangan karena merugikan tidak hanya bagi diri sendiri tetapi orang lain. Mencontek adalah suatu kegiatan menghilangkan nilai-nilai yang berharga dengan melakukan ketidakjujuran atau penipuan.

Menurut Kelley R Taylor (2003) mencontek didefinisikan sebagai mengikuti sebuah ujian dengan melalui jalan yang tidak jujur, menjawab pertanyaan dengan cara yang tidak semestinya.

\section{Gejala dan Bentuk Perilaku Mencontek}

Siswa memiliki yang self efficacy rendah (low selfefficacy) merupakan indikasi yang lain dalam perilaku mencontek. Self- 
efficacy adalah kepercayaan seseorang tentang kemampuan diri dalam bertindak, sehingga dalam self-efficacy diperlukan adanya kecakapan. Istilah self-efficacy dapat dimaknai sebagai keyakinan diri seseorang dalam menyelesaikan suatu tugas atau permasalahan

Siswa yang tidak memiliki motivasi berprestasi dalam belajar menjadi gejala yang muncul pada periku mencontek peserta didik. Pendapat tersebut dipaparkan oleh Pintrich dan Bong (dalam Hartanto, 2012) yang menyatakan bahwa peserta didik yang memiliki motivasi belajar rendah akan menyelesaikan pekerjaan yang diberikan dengan apa adanya dan lebh memilih untuk meminta bantuan dari orang lain.

Ada empat bentuk mencontek menurut Hetherington and Feldman (1964) yaitu: individualistic-opportunistic, individualistic planned, social-active, and social-passive. Individualistic-opportunistic dapat dimaknai sebagai perilaku dimana peserta didik mengganti suatu jawaban ketika ujuan atau tes sedang berlangsung dengan menggunakan catatan ketika guru keluar dari kelas. Individualistic-planned dapat diidentifikasi sebagai menggunakan catatan ketika tes atau ujian berlangsung, atau membawa jawaban yang telah lengkap atau dipersiapkan dengan menulisnya terlebih dahulu sebelum berlangsungnya ujian.Ketiga, social-active adalah perilaku mencontek dimana siswa mengcopi atau melihat atau meminta jawaban dari orang lain. Sementara social-passive adalah mengijinkan seseorang untuk melihat atau mengcopi jawabannya. Menurut Baird (Anderman \& Murdock, 2007) perilaku yang paling sering dijumpai dalam mencontek adalah: meminta informasi atau jawaban dari orang atau teman yang lain, memberikan ijin kepada orang lain untuk menyalin pekerjaannya, menyalin tugas orang lain, plagiarizing.
Hal yang sama dinyatakan dalam survey yang dilakukan oleh Franklyn-Stokes dan Newstead (Anderman \& Murdock, 2007) bahwa memberikan ijin kepada orang atau teman yang lain untuk menyalin pekerjaan merupakan peringkat pertama (72 persen), peringkat kedua adalah mengerjakan pekerjaan orang lain (66 persen), menyalin atau mencatat tanpa mencantumkan sumber literatur (66 persen), dan menyalin pekerjaan orang atau teman yang lain tanpa pengetahuan yang bersangkutan (64 persen). Survey terbaru Dawkins (Anderman \& Murdock, 2007) menunjukkan perubahan perilaku mencontek yaitu dengan menyalin dari internet.

\section{Penyebab Perilaku Mencontek}

Faktor-faktor umum yang menyebabkan terjadinya perilaku mencontek adalah: adanya kemalasan pada diri seseorang, karena merasa strees, melihat perilaku mencontek bukan merupakan hal yang salah dan merugikan, dan sebagian yang lain mencontek karena memiliki keyakinan bahwa perilakunya tidak akan diketahui.

Perilaku mencontek meningkat dengan adanya hubungan sosial yang terjadi diantara peserta didik di sekolah. Hal ini terjadi karena siswa belajar mencontek dari teman-temannya dan kemudian belajar untuk menerima bahwa hal tersebut bukan merupakan perilaku yang salah. Pendapat tersebut didukung oleh Lambert (dalam Hartanto, 2012) penyebab seorang individu mencontek adalah:

a. Adanya tekanan untuk mendapatkan nilai yang tinggi,

Pada dasarnya setiap peserta didik memiliki keinginan yang sama yaitu mendapatkan nilai yang baik (tinggi). Keinginan tersebut terkadang membuat peserta didk menghalalkan segala 
cara, termasuk dengan melakukan mencontek.

b. Keinginan untuk menghindari kegagalan,

Ketakutan peserta didik mendapat kegagalan di sekolah merupakan hal yang sering dialami oleh peserta didik. Kegagalan yang dimaksud antara lain dalam bentuk (takut tidak naik kelas, takut mengikuti ulangan susulan) tersebut memicu terjadinya perilaku mencontek.

c. Adanya persepsi bahwa sekolah melakukan hal yang tidak adil,

Sekolah dianggap hanya memberikan akses bagi siswa-siswi yang cerdas dan berprestasi sehingga siswa-siswi yang memiliki kemampuan menengah merasa tidak diperhatikan dan dilayani dengan baik

d. Kurangnya waktu untuk menyelesaikan tugas sekolah,

Siswa terkadang mendapatkan tugas secara bersamaan. Waktu penyerahan tugas dalam waktu yang bersamaan membuat siswa tidak dapat membagi waktunya.

e. Tidak adanya sikap untuk menentang perilaku mencontek di sekolah.

Perilaku mencontek di sekolah kadang dianggap sebagai suatu permasalahan yang biasa baik oleh siswa maupun oleh guru. Sehingga banyak peserta didik yang membiarkan perilaku ini atau terkadang justru membantu terjadinya perilaku mencontek.

\section{Akibat mencontek}

Akibat buruk mencontek diantaranya adalah menurunnya rasa percaya diri dan kreativitas peserta didik dalam jangka pendek atau pun jangka panjang. Peserta didk yang mempunyai kebiasaan mencontek akan selalu merasa tidak percaya dengan apa yang dirinya kerjakan.

Dalam menyelesaikan soal ada perasaan tidak yakin sehingga selalu ingin melihat pekerjaan orang lain dan membandingkannya. Hal ini akan berakibat siswa tersebut tidak mau lagi menyelesaikan soal dan lebih memilih melihat pekerjaan orang lain kemudian menyalinnya. Lamakelamaan tidak akan ada ide-ide orisinil yang keluar dari pemikiran yang mengakibatkan tidak bisa berkreasi.

Dampak yang timbul dari praktek mencontek yang secara terus menerus dilakukan akan mengakibatkan ketidakjujuran Jika tidak, niscaya akan muncul malapetaka: peserta didik akan menanam kebiasaan berbuat tidak jujur, yang pada saatnya nanti akan menjadi kandidat koruptor.

\section{TEORI VARIABEL TINDAKAN}

\section{Konsep Bimbingan Kelompok}

Bimbingan kelompok sebagai alternatif dalam menurunkan kebiasaan mencontek, karena dalam layanan bimbingan kelompok para peserta didik diajak untuk bersama-sama mengemukakan pendapat tentang sesuatu dan membicarakan topic-topik penting, mengembangkan nilai-nilai tentang hal tersebut dan mengembangkan langkah-langkah bersama untuk menangani permasalahan yang dibahas dalam kelompok.

\section{Tujuan dan fungsi bimbingan kelompok}

\section{Bimbingan kelompok bertujuan} agar peserta didik terlibat secara aktif dan tumbuhnya kebersamaan dalam memecahkan suatu persoalan sekaligus memperoleh bahan 
dari nara sumber (guru pembimbing) yang akan sangat bermanfaat bagi kehidupannya, baik sebagai makhluk individu maupun makhluk sosial.

Bimbingan kelompok mempunyai 3 (tiga) fungsi yaitu :

1. Berfungsi informatif.

2. Berfungsi pengembangan.

3. Berfungsi preventif dan kreatif.

Fungsi utama yang didukung dalam bimbingan kelompok adalah fungsi pemahaman dan pengembangan.

\section{Langkah-langkah Penyelenggaraan Bimbingan Kelompok}

Penyelenggaraan layanan boimbingan kelompok diawali dengan pembentukan kelompok Dalam pembentukan kelompok, kelompok dapat dipilih secara homogen baik ditinjau dari jenis kelamin, prestasi akademik maupun berdasasrkan kedekatan jarak, dapat pula dipilih secara heterogen. Untuk beberapa hal kelompok heterogen akan lebih efektif untuk meningkatkan kerjasama dan saling membantu.

Adapun tahap-tahap pelaksanaan bimbingan kelompok adalah :

1. Tahap Pembentukan Kelompok.

Pada tahap ini anggota kelompok diarahkan untuk mengetahui tujuan dibentuknya kelompok.

2. Tahap Peralihan.

Tahap ini merupakan tahapan untuk meninjau pemahaman anggota kelompok terhadap apa yang akan dilaksanakannya.

3. Tahap Kegiatan.

Tahap dilaksanakannya kegiatan.

4. Tahap Pengakhiran.

Tahap ini merupakan tahap pengecekan terhadap apa yang dicapai anggota kelompok (tahap evaluasi), termasuk penyampaian kesan dan pesan setelah mengikuti kegiatan kelompok.

\section{Pendekatan Active Learning dengan metode Apa? Lantas bagaimana? Dan Sekarang bagaimana?}

Metode Apa? Lantas Bagaimana? Dan Sekarang Bagaimana? merupakan sebuah pendekatan active learning untuk bagaimana membantu peserta didik mendapatkan pengetahuan, ketrampilan dan sikap secara aktif. Dalam metode ini nilai dari aktivitas belajar eksperiensial akan meningkat dengan meminta peserta didik untuk merenungkan kembali pengalaman yang baru mereka alami dan menggali implikasinya. Periode perenungan seringkali disebut sebagai pengolahan atau debriefing (pewawancaraan-pentanyajawaban). Sebagian kalangan pendidik kini menggunakan istilah harvesting (pemanenan). Berikut adalah urutan tiga tahap untuk memanen pengalaman yang kaya akan pembelajaran. Prosedur pelaksanaan:

1. Kondisikan peserta didik ke dalam pengalaman yang sesuai dengan topik yang anda ajarkan. Pengalaman-pengalaman ini mencakup permainan atau simulasi, kunjungan lapangan, tayangan video proyek belajar praktik,debat, drama, dan latihan amajinasi mental

2. Perintahkan peserta didik untuk saling bercerita tentang apa yang terjadi pada mereka selama latihan tersebut, seperti "Apa yang mereka lakukan?", "Apa yang meraka amati? Pikirkan?”, dan “Apa yang mereka rasakan selama latihan itu?"

3. Selanjutnya perintahkan peserta didik untuk bertanya pada diri sendiri, "Lantas, Bagaimana?", seperti "manfaat apa yang mereka dapatkan dari latihan tu?"“"apa yang mereka pelajari? Dan pelajari kembali?, “apa implikasi dari aktivitas itu?", dan "bagaimanakah kaitan antara pengalaman itu (jika itu berupa simulasi atau drama) dengan dunia nyata?"

4. Terakhir perintahkan peserta didik untuk memikirkan,"Sekarang bagaimana?", 
seperti "bagaiman kalian ingin melakukan sesuatu secara berbeda di masa mendatang?", "bagaimana kalian dapat memperluas pembelajaran yang kalian dapatkan?", "Langkah-langkah apa yang dapat kalian ambil untuk menerapkan apa yang telah kalian pelajari?"

\section{VARIASI}

Batasi diskusi pada "Apa?"dan "Lantas bagaimana?". Gunakan kedua pertanyaan ini untuk menstimulir penulisa jurnal (lihat strategi. 61, "Jurnal Belajar").

\section{METODE PENELITIAN}

\section{Jenis Penelitian dan Metode Penelitian.}

Penelitian ini adalah penelitian tindakan kelas (class room action research) yang dilaksanakan dengan empat tahapan yaitu, rencana tindakan, pelaksanaan tindakan, observasi dan refleksi sesuai dengan model PTK oleh Kemmis \& Mc. Taggart, yang dilaksanakan secara kolaboratif dan partisipasif antara guru BK (sebagai peneliti) dengan teman sejawat sebagai observer dalam penelitian ini.

Penelitian tindakan kelas ini dilakukan dalam layanan bimbingan kelompok menggunakan metode "Apa? Lantas, Bagaimana?

\section{Subyek Penelitian}

Subyek penelitian adalah peserta didik kelas VIII.1 di SMP N I Citeureup yang berjumlah 44 orang yang terdiri dari 21 lakilaki dan 23 perempuan.

\section{Prosedur Kerja Penelitian.}

Prosedur kerja penelitian dirancang menjadi dua siklus yaitu:

1. Siklus 1 dilakukan 1 kali pertemuan dalam seminggu

2. Siklus 2 dilakukan 1 kali pertemuan dalam seminggu

\section{Rencana Tindakan.}

Peneliti membuat perencanaan yaitu membentuk kelompok menjadi 6 kelompok yang terdiri dari 7 atau 8 anggota, menyiapkan satuan layanan, menentukan metode, menyusun kuisioner kebiasaan mencontek, membuat lembar observasi untuk kolabirator dan angket peserta didik yang diberikan sebelum dan sesudah peserta didik mendapat perlakuan/ tindakan.

\section{Pelaksanaan Tindakan}

Pelaksanaan tindakan ini meliputi penelitian tindakan kelas dengan seting tahapan bimbingan kelompok dan tahapan metode yang digunakan sebagai treatment terhadap perilaku mencontek.

\section{Sumber Data}

Pada penelitian tindakan kelas ini, sumber data diperoleh dari :

1. Data (Proses) diperoleh dari peneliti dalam memberikan layanan bimbingan kelompok, dan peserta didik sewaktu mengikuti layanan dan situasi pada saat layanan.

2. Data (Hasil) diperoleh dari pengamatan terhadap peserta didik berupa hasil tindakan umtuk menurunkan kebiasaan mencontek. Data ini merupakan hasil pengamatan dengan kolaborator yang dituangkan dalam tahap refleksi pada tiap - tiap siklus.

\section{HASIL DAN PEMBAHASAN}

\section{Deskrispsi Hasil Bimbingan Kelompok Siklus 1}

Penelitian tindakan ini dirancang dan dilaksanakan menjadi dua siklus yaitu siklus 1 pada tanggal 29 September 2012 dan siklus 2 pada tanggal 18 Oktober 2012. Setiap siklus dilaksanakan satu kali pertemuan selama dua jam pelajaran (80 menit). 
Penelitian tindakan ini didasarkan pada hasil pretest yang dilaksanakan sebelum pelaksanaan tindakan di kelas VIII.1 yang berjumlah 44 peserta didik dalam bentuk bimbingan kelompok.

Dari hasil pretest diperoleh data kebiasaan mencontek 21 peserta didik dalam kategori tinggi, 20 peserta didik kategori sedang dan 3 peserta didik kategori rendah.

Selanjutnya peserta didik diberikan tindakan secara kelompok dengan menggunakan metode apa? Lantas bagaimana dan Sekarang bagaimana?

Selama melaksanakan tindakan ,peneliti yang sekaligus berperan sebagai guru BK diobservasi tentang kesesuain antara perencanaan yang telah dibuat dengan prosedur pelaksanaan tindakan dan keaktifan peserta didik selama mengikuti kegiatan bimbingan kelompok oleh teman sejawat yang sekaligus bertindak sebagai kolaborator.

\section{Deskripsi Siklus 1}

\section{Prosedur Pelaksanaan Tindakan.}

Berdasarkan hasil pengamatan observer, guru BK telah melaksanakan tindakan secara sistimatis dan sesuai dengan langkah -langkah prosedur kegiatan yang telah direncanakan dalam satuan layanan, yaitu mencapai $94,49 \%$. Dan 5, $51 \%$ belum sesuai dengan prosedur pelaksanaan tindakan karena masalah yang dibahas kurang mendalam.

\section{Data Keaktifan Peserta Didik}

Hasil observasi aktivitas peserta didik menunjukkan bahwa tingkat keaktifan peserta didik mencapai $77,6 \%$ seperti yang ditunjukkan dalam grafik berikut ini:

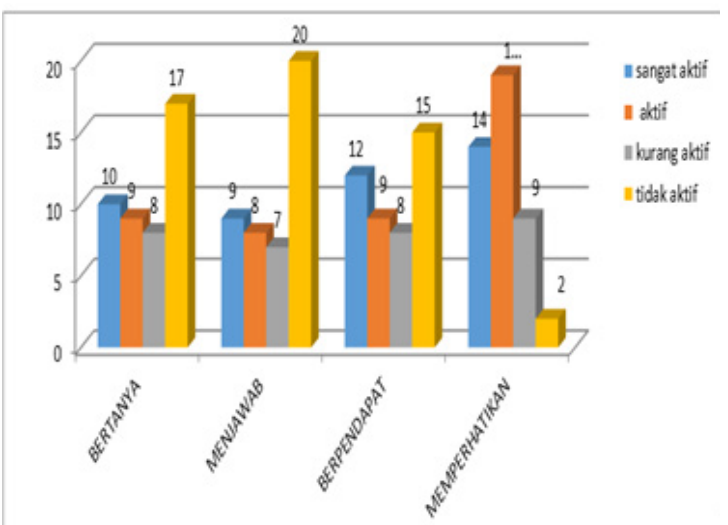

Grafik 1.Grafik Data Keaktifan Peserta Didik pada Siklus 1

\section{Data Respon Peserta Didik}

Berdasarkan analisa hasil responden peserta didik yang berkaitan dengan pemahaman materi, penggunaan metode, media dan ditinjau secara keseluruhan tentang pelaksanaan tindakan diperoleh data bahwa $80 \%$ siswa menyatakan puas secara keseluruhan dan $20 \%$ siswa menyatakan tidak puas. Secara rinci dapat dilihat dalam grafik berikut ini:

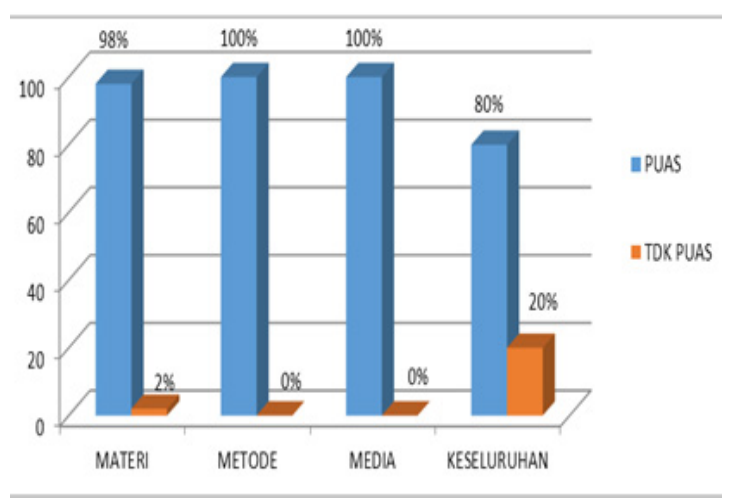

Grafik 2.Grafik Data Respon Peserta Didik Siklus 1

\section{Hasil}

Selanjutnya di akhir siklus 1 peserta didik diberikan posttest. Dari hasil posttest secara keseluruhan menunjukkan adanya 
penurunan kebiasaan mencontek dari $48 \%$ sebelum diberi tindakan menjadi $45 \%$ setelah tindakan seperti yang terlihat dalam tabel berikut:

Tabel 1. Data Peserta Didik per Siklus

\begin{tabular}{llll}
\hline Persentase & \multicolumn{1}{c}{ Siklus 1} & \multicolumn{1}{c}{ Siklus 2 } & Kategori \\
\hline $49 \%-60 \%$ & 21 siswa & 18 siswa & Tinggi \\
$37 \%-48 \%$ & 20 siswa & 18 siswa & Sedang \\
$25 \%-36 \%$ & 3 siawa & 8 siswa & Rendah \\
\hline
\end{tabular}

\section{Deskripsi Siklus 2}

Di akhir siklus 1 setelah posttest guru BK (peneliti) bersama kolaborator melakukan refleksi untuk mengetahui kelemahan/ kekurangan selama melaksanakan tindakan. Berdasarkan hasil refleksi ditemukan beberapa kelemahan sehingga belum dapat dilaksanakan secara optimal oleh guru BK (Peneliti). Temuan-temuan tersebut dijadikan sebagai rekomendasi untuk dilaksanakan pada siklus 2 .

\section{Prosedur Pelaksanaan Tindakan.}

Berdasarkan hasil pengamatan teman sejawat guru BK telah melaksanakan tindakan secara sistimatis dan sesuai dengan langkah -langkah prosedur kegiatan yang telah direncanakan dalam satuan layanan, yaitu mencapai $100 \%$.

\section{Data Keaktifan Peserta Didik}

Berdasarkan pengamatan pada siklus 2 diperoleh data bahwa tingkat keaktifan peserta didik dalam mengikuti kegiatan bimbingan kelompok meningkat dari $77,6 \%$ pada siklus 1 menjadi 83,2 \% dengan kategori berikut ini:

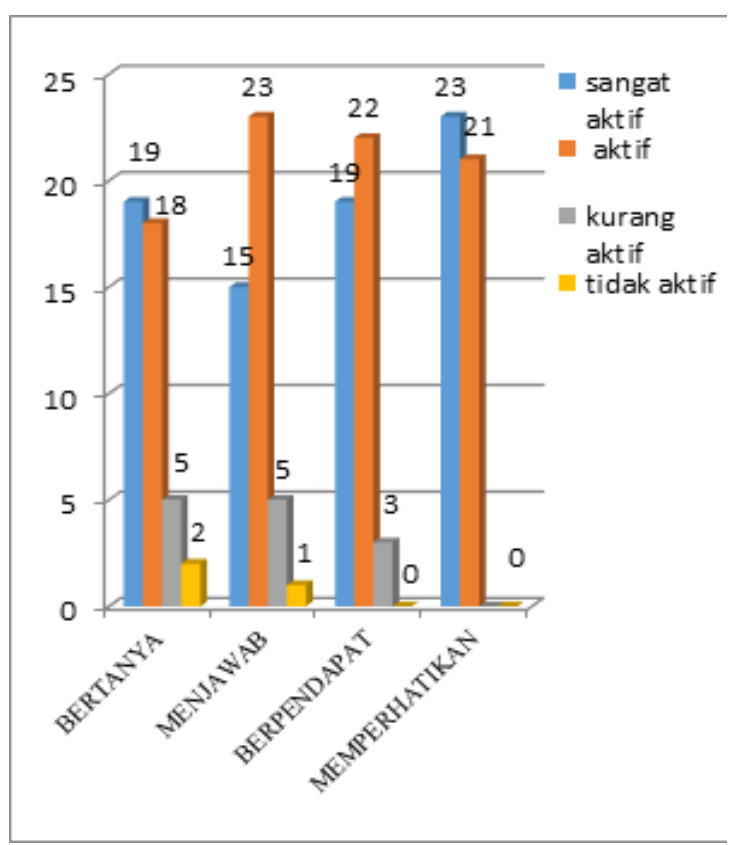

Grafik 3. Grafik Data Keaktifan Peserta Didik pada Siklus 2

\section{Data Respon Peserta Didik}

Berdasarkan analisa hasil responden peserta didik yang berkaitan dengan pemahaman materi, penggunaan metode, media dan ditinjau secara keseluruhan tentang pelaksanaan tindakan terjadi peningkatan dari $80 \%$ peserta didik menyatakan puas secara keseluruhan pada siklus 1 menjadi $95 \%$ pada siklus 2. Secara rinci dapat dilihat dalam grafik berikut ini: 


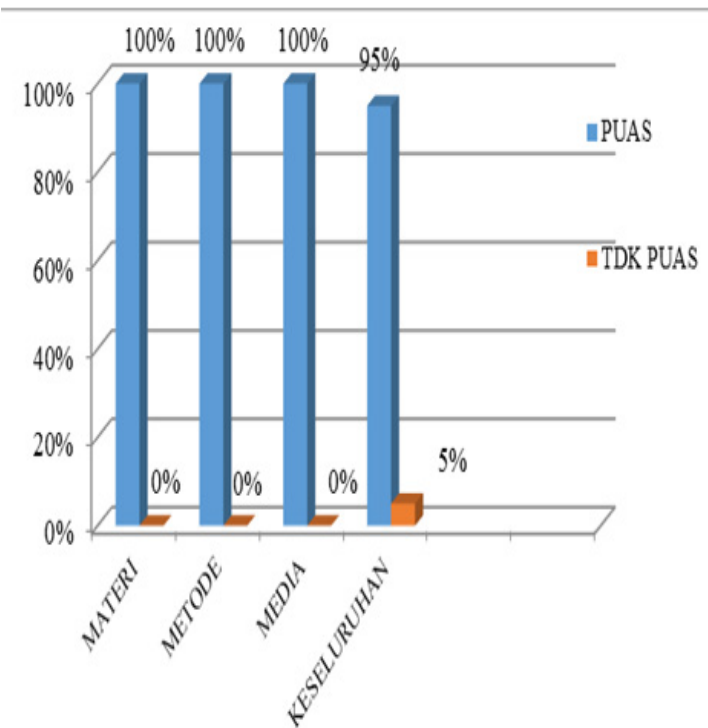

Grafik 5. Grafik Data Respon Peserta Didik pada Silus 2

\section{Hasil}

Selanjutnya di akhir siklus 2 peserta didik diberikan posttest. Dari hasil posttest secara keseluruhan menunjukkan adanya penurunan kebiasaan mencontek dari $45 \%$ pada siklus 1 menjadi $40 \%$ pada siklus 2 seperti yang terlihat dalam table berikut:

Tabel 2. Data Peserta Didik per Siklus

\begin{tabular}{llll}
\hline Persentase & Siklus 1 & Siklus 2 & Kategori \\
\hline $49 \%-60 \%$ & 18 siswa & 9 siswa & Tinggi \\
$37 \%-48 \%$ & 18 siswa & 15 siswa & Sedang \\
$25 \%-36 \%$ & 8 siswa & 20 siswa & Rendah \\
\hline
\end{tabular}

Sebagai bahan perbandingan secara keseluruhan hasil penelitian tindakan terhadap kebiasaan mencontek dari sebelum tindakan, siklus 1 dan siklus 2 dapat dilihat dalam tabel berikut ini:

Tabel 3. Data Keseluruhan Hasil Penelitian

\begin{tabular}{lcccc}
\hline Persentase & $\begin{array}{c}\text { Pra } \\
\text { Siklus }\end{array}$ & Siklus 1 & Siklus 2 & $\begin{array}{c}\text { Kate- } \\
\text { gori }\end{array}$ \\
\hline $49 \%-60 \%$ & 21 siswa & 18 siswa & 9 siswa & Tinggi \\
$37 \%-48 \%$ & 20 siswa & 18 siswa & 15 siswa & \begin{tabular}{l} 
Sedang \\
\hline
\end{tabular}
\end{tabular}

25\%-36\% 3 siswa 8 siswa 20 siswa Rendah

Dengan demikian berdasarkan data
tersebut di atas maka Metode Apa? Lantas Bagaimana? Dan Sekarang Bagaimana dalam bimbingan kelompok terbukti dapat menurunkan kebiasaan mencontek pada peserta didik kelas VIII.1 SMP N 1 Citeureup.

\section{KESIMPULAN DAN SARAN}

\section{Kesimpulan}

Berdasarkan hasil analisis data dan hasil pengamatan maka dapat disimpulkan bahwa Metode Apa? Lantas Bagaimana? Dan Sekarang Bagaimana dalam Bimbingan Kelompok

1. Lebih menyenangkan, menarik perhatian, lebih diminati dan mudah dipahami karena relevan dengan upaya menurunkan kebiasaan mencontek.

2. Dari hasil observasi metode tersebut dapat meningkatkan keaktifan peserta didik dari $77,6 \%$ menjadi $83,2 \%$.

3. Dapat menurunkan kebiasaan mencontek dari $45 \%$ menjadi $40 \%$.

\section{Saran}

1. Bagi Guru BK:

Guru BK dalam memberikan layanan bimbingan kelompok diharapkan dapat menggunakan Metode Apa? Lantas Bagaimana? Dan Sekarang Bagaimana? lebih kreatif dan inovatif untuk menurunkan kebiasaan mencontek.

\section{Bagi Guru Mata Pelajaran}

Guru mata pelajaran lebih kreatif dan inovatif dalam membuat soal-soal ulangan dan memberikan penilaian yang melibatkan aspek kognitif, afektif, emosi dan spiritual serta melakukan pengawasan ketat dalam melaksanakan kegiatan ulangan. 


3. Bagi Sekolah
Sekolah hendaknya dapat
mendukung sepenuhnya r agar
kegiatan layanan ini dapat dilakukan
secara menyeluruh, terprogram dan
berkesinambungan.

\section{DAFTAR PUSTAKA}

Anderman, E.M., \& Murdock, T.B. (2007).

Psychology of Academic Cheating .USA.

Alfie Kohn

Hartanto, D. (2012). Bimbingan \& Konseling; Menyontek: Mengungkap Akar Masalah dan Solusinya. Jakarta: INDEKS.

Hetherington, E.M., \& Feldman, S.E. (1964). College Ceharting as a Function of Subject and Situational Variables. Journal fof Educational Psychlogym 55.

Taylor, R Kelley. (2003). Cheater, Cheater... Reston: National Association of Secondary School Principals 